\title{
Effects of Dietary Level of Protein on the Maintenance Energy Requirement and Net Energetic Efficiency for Growth of Post-Weaning Rats
}

\author{
Katsumi IMAI, ${ }^{*}$ Masaharu OHNAKA, and Yoshiaki NIIYAMA ${ }^{1}$ \\ Department of Nutrition, School of Medicine, The University of Tokushima, \\ 3-Kuramoto-cho, Tokushima 770, Japan
}

(Received June 4, 1986)

\begin{abstract}
Summary The effects of dietary protein on the maintenance energy requirement $(\mathrm{MEm})$ and net utilization efficiency of metabolizable energy for growth $(\mathrm{MEg})$ were investigated by regression analysis of energy balance with various energy intakes. Weanling rats of the Wistar strain, weighing about $85 \mathrm{~g}$, were given a diet containing 0 to $70 \%$ casein freely or in restricted amounts (equivalent to two-thirds or one-third of the intake of the ad libitum group) for 5 days. The MEm was fairly constant in rats given 10 to $50 \%$ casein diets, being about $29 \mathrm{kcal} / 100 \mathrm{~g} \mathrm{BW} / \mathrm{day}$, but increased at higher or lower dietary protein levels, indicating inefficient energy utilization in protein-malnourished animals. From the slope of the regression line between energy balance and metabolizable energy intake, the net energetic efficiencies for growth were estimated as $68,71,74,77,82$, $83,80,78,77$ and $74 \%$ with $0,3,6,10,20,30,40,50,60$ and $70 \%$ casein diets, respectively. Weanling rats fed 20 to $30 \%$ casein diets utilized the dietary energy for growth most efficiently. At protein levels higher or lower than 20 to $30 \%$, the efficiency was less, showing that MEg utilization depended on dietary protein. The energy necessary for $1 \mathrm{~g}$ body weight gain was $2.6 \mathrm{kcal}$ in rats receiving $30 \%$ casein diet, but increased with an increase or decrease in the protein level. These data on the food efficiency, $\mathrm{MEm}$, the net efficiency of $\mathrm{MEg}$ and the energy necessary for $1 \mathrm{~g}$ weight gain show that dietary protein affects energy utilization and that proteinmalnourished animals use energy inefficiently.
\end{abstract}

Key Words maintenance energy, net energetic efficiency, dietary protein, regression analysis

1 今井克己，大中政治，新山喜昭

* Present address: Department of Food and Nutrition, Nakamura Gakuen College, 5-chome, Befu, Jounan-ku, Fukuoka 814, Japan. 
In growing animals, metabolizable energy (ME) from a diet is used for growth (MEg) and maintenance (MEm) including fasting heat production, diet-induced thermogenesis (DIT) and physical activities. With regard to effective utilization of feed energy in animals, particularly livestock, it is important to elucidate the net efficiency of MEg. Utilization of nutrients may be influenced by the quantity and quality of diets as well as by the chronological and physiological conditions of the animals (1). For example, utilization of dietary protein increases with increase in energy intake, a phenomenon known as protein sparing. However, there have been few studies on the effects of dietary protein on energy utilization.

In addition, from the viewpoint of preventing obesity, it is also important to know the extent of MEm in animals receiving various amounts of dietary protein. Thus, we studied the utilization efficiency of $\mathrm{MEg}$ and the extent of MEm in weanling rats receiving different amounts of dietary protein by regression analysis of energy balance at four levels of energy intake.

\section{MATERIALS AND METHODS}

A total of 175 male weanling rats of the Wistar strain, weighing about $85 \mathrm{~g}$, were used. One group of 10 rats was killed to determine the initial body composition. Another group of 5 rats was used to observe the energy balance during a 5-day period of starvation. The rest of the animals were divided into 10 groups and were given a diet containing $0,3,6,10,20,30,40,50,60$ or $70 \%$ casein freely or

Table 1. Compositions $(\mathrm{g} / \mathrm{kg})$ of experimental diets.

\begin{tabular}{|c|c|c|c|c|c|c|c|c|c|c|}
\hline & $0 \%$ & $3 \%$ & $6 \%$ & $10 \%$ & $20 \%$ & $30 \%$ & $40 \%$ & $50 \%$ & $60 \%$ & $70 \%$ \\
\hline Casein & - & 30 & 60 & 100 & 200 & 300 & 400 & 500 & 600 & 700 \\
\hline $\begin{array}{l}\text { L-Methio- } \\
\text { nine }^{\mathrm{a}}\end{array}$ & - & 0.5 & 0.9 & 1.5 & 3.0 & 4.5 & 6.0 & 7.5 & 9.0 & 10.5 \\
\hline$\alpha-$ Starch & 578 & 558 & 540 & 511 & 445 & 376 & 308 & 240 & 172 & 102 \\
\hline Sucrose & 289 & 279 & 270 & 256 & 222 & 188 & 154 & 120 & 86 & 51 \\
\hline Salt mix. ${ }^{b}$ & 50 & 50 & 50 & 50 & 50 & 50 & 50 & 50 & 50 & 50 \\
\hline $\begin{array}{l}\text { Vitamin } \\
\text { mix. }^{\text {b }}\end{array}$ & 10 & 10 & 10 & 10 & 10 & 10 & 10 & 10 & 10 & 10 \\
\hline Cellulose & 20 & 20 & 20 & 20 & 20 & 20 & 20 & 20 & 20 & 20 \\
\hline Oil & 50 & 50 & 50 & 50 & 50 & 50 & 50 & 50 & 50 & 50 \\
\hline Chocola $^{c}{ }^{c}$ & 0.5 & 0.5 & 0.5 & 0.5 & 0.5 & 0.5 & 0.5 & 0.5 & 0.5 & 0.5 \\
\hline Choline- $\mathrm{Cl}$ & 5 & 5 & 5 & 5 & 5 & 5 & 5 & 5 & 5 & 5 \\
\hline$\alpha$-Tocopherol & 0.5 & 0.5 & 0.5 & 0.5 & 0.5 & 0.5 & 0.5 & 0.5 & 0.5 & 0.5 \\
\hline Energy $^{d}$ & 3.89 & 3.84 & 3.90 & 4.01 & 4.07 & 4.17 & 4.33 & 4.48 & 4.61 & 4.59 \\
\hline
\end{tabular}

${ }^{\mathrm{a}} \mathrm{L}$-Methionine was added at $1.5 \mathrm{~g}$ per $100 \mathrm{~g}$ casein. ${ }^{\mathrm{b}}$ Harper's mixture. ${ }^{\mathrm{c}}$ One $\mathrm{ml}$ of Chocola A contains $20 \mathrm{mg}$ (30,000 IU) of retinyl palmitate. ${ }^{\mathrm{d}}$ Energy contents, expressed as $\mathrm{kcal} / \mathrm{g}$ of diet, were measured in a bomb-calorimeter (Shimadzu CA-3). 
in restricted amounts equivalent to $2 / 3$ and $1 / 3$, respectively, of the intake of those fed ad libitum, for 5 days (Table 1).

All animals were housed individually in a metabolic chamber maintained at $23 \pm 1{ }^{\circ} \mathrm{C}$ with a $12 \mathrm{~h}-12 \mathrm{~h}$ light-dark cycle. Their expired air was collected in a Douglas-bag by aspiration at a rate of $200 \mathrm{ml} / \mathrm{min}$ throughout the 5-day feeding period. The $\mathrm{O}_{2}$ and $\mathrm{CO}_{2}$ in the expired air were analyzed with a paramagnetic $\mathrm{O}_{2}$ analyzer (Horiba PMA-200) and a nondiffusible infrared $\mathrm{CO}_{2}$ analyzer (Horiba VIA-210), respectively, after removal of moisture. Then the volume of expired air was measured, and energy expenditure was computed indirectly.

Urine and feces were collected for determination of their energy contents throughout the period. Food intake and body weight were measured daily. The energy balance of each group was calculated by subtracting the energy expenditure from the metabolizable energy.

For comparison of the extent of energy storage obtained by the balance method with that by the slaughter method, all animals were killed by decapitation on the morning of day 6 . The liver, kidneys, heart and spleen were removed and weighed. The stomach and intestine were resected and their contents were washed out with saline. The carcass combined with these organs was dried to constant weight at $105^{\circ} \mathrm{C}$ to determine the nitrogen and fat contents.

Nitrogen in the carcasss, feces and urine was determined by the semimicroKjeldahl method. The fat content of the carcass was measured gravimetrically with a Goldfisch apparatus after hot ether extraction. Protein- and fat-energy in the body were calculated by multiplying the amounts of protein and fat by 5.74 and 9.30 $\mathrm{kcal} / \mathrm{g}$, respectively. The initial contents of body protein and fat were calculated by equations derived from the significant relations found between the body weight of

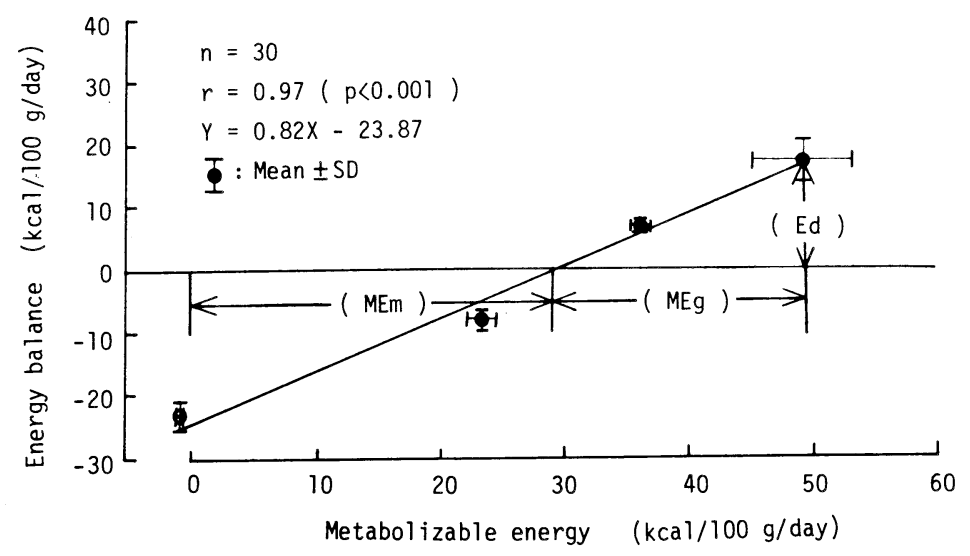

Fig. 1. Relation between energy intake and energy balance in animals fed $20 \%$ casein diet. Metabolizable energy $(\mathrm{ME})=\mathrm{ME}$ for maintenance $(\mathrm{MEm})+\mathrm{ME}$ for growth $(\mathrm{MEg})$. Energy balance $=\mathrm{ME}-$ energy expenditure $=$ energy deposited $(\mathrm{Ed})$. Net energetic efficiency for growth $=\mathrm{Ed} / \mathrm{MEg}=0.82$. 
about $85 \mathrm{~g}$ and the contents of body protein and fat, respectively:

$$
\begin{aligned}
\text { protein }(\%) & =-0.0826 \mathrm{BW}(\mathrm{g})+21.97 \\
\text { fat }(\%) & =0.1445 \mathrm{BW}(\mathrm{g})-0.84
\end{aligned}
$$

The energy contents of the diet and feces were determined with a bomb calorimeter (Shimadzu CA-3 Type). A preliminary experiment showed that urinary energy is proportional to urinary nitrogen, therefore, the energy content of the urine was calculated by multiplying the urinary nitrogen by a factor of $7.90 \mathrm{kcal} / \mathrm{g} \mathrm{N}$.

The net, not gross, utilization efficiency, of metabolizable energy for growth (MEg) was estimated by regression analysis of energy balance (EB) vs. metabolizable energy (ME) intake. As shown in Fig. 1, a linear relationship between $\operatorname{ME~(~} X$, intake energy - energy in urine and feces) and $\mathrm{EB}(Y, \mathrm{ME}$ - energy expenditure) was obtained in animals given $20 \%$ casein diet at various levels of energy intake. The $X$ intercept of this line represents the metabolizable energy for maintenance (MEm), because EB is zero at this energy intake. The remaining part of ME, designated as $\mathrm{MEg}$, is the energy used for growth. As the extent of positive energy balance (Ed) is the net energy deposited in tissues, the ratio of Ed to $\mathrm{MEg}$ represents the net efficiency of energy for growth.

\section{RESULTS}

\section{Effect of 5-days starvation on energy expenditure}

As we anticipated that daily total energy expenditure would decrease during starvation or food-restriction, due to reductions in body weight and physical activities, we first examined the changes in energy expenditure during 5-days starvation. Results showed that it decreased from 24.75 on day 1 to about $23 \mathrm{kcal} /$ $100 \mathrm{~g} \mathrm{BW/day} \mathrm{on} \mathrm{day} 2$ and thereafter remained constant (Table 2). Thus, in regression analysis of energy balance with various metabolizable energy intakes, the mean values of energy expenditure in the final 3 days were used.

Table 2. Changes in energy balance during 5-days starvation.

\begin{tabular}{lrrrrrrr}
\hline & \multicolumn{7}{c}{ Day of starvation } \\
\cline { 2 - 8 } & \multicolumn{1}{c}{1} & 2 & 3 & 4 & 5 & 6 \\
\hline Body weight (g) & 96.8 & 85.5 & 80.0 & 75.2 & 71.1 & 69.5 \\
Energy expenditure & & & & & & \\
$\quad(\mathrm{kcal} /$ day $)$ & 22.57 & 18.98 & 17.4 & 16.08 & 16.25 \\
$\quad \mathrm{kcal} / 100 \mathrm{~g} /$ day) & 24.75 & 22.94 & 22.42 & 21.96 & 23.38 \\
Energy in urine (kcal/100 g/day) & 0.53 & 0.53 & 0.53 & 0.53 & 0.53 \\
Energy in feces (kcal/100 g/day) & 0.60 & 0.62 & 0.32 & 0.32 & 0.32 \\
Energy balance (kcal/100 g/day) & -25.86 & -24.11 & -23.29 & -22.90 & -24.35 \\
\hline
\end{tabular}


Table 3. Food intakes and changes in body weight during a 5-day feeding period in weanling rats fed ad libitum.

\begin{tabular}{|c|c|c|c|c|c|}
\hline \multirow{2}{*}{$\begin{array}{c}\text { Casein level } \\
(\%)\end{array}$} & \multirow[b]{2}{*}{ No. of rats } & \multicolumn{2}{|c|}{ Intake } & \multirow[b]{2}{*}{$\begin{array}{l}\text { Weight gain } \\
\text { (g/5 days) }\end{array}$} & \multirow[b]{2}{*}{$\begin{array}{c}\text { Food } \\
\text { efficiency }\end{array}$} \\
\hline & & $\begin{array}{c}\text { Food } \\
\text { (g/5 days) }\end{array}$ & $\begin{array}{l}\text { Protein } \\
\text { (g/5 days) }\end{array}$ & & \\
\hline 0 & 5 & $39.3 \pm 1.5^{\mathrm{a}}$ & - & -10.6 & - \\
\hline 3 & 5 & $46.3 \pm 8.4$ & $1.2 \pm 0.2$ & -5.6 & - \\
\hline 6 & 5 & $78.7 \pm 8.3$ & $3.9 \pm 0.4$ & 20.5 & 0.26 \\
\hline 10 & 5 & $69.6 \pm 3.4$ & $5.8 \pm 0.3$ & 28.9 & 0.42 \\
\hline 20 & 10 & $73.8 \pm 5.9$ & $12.3 \pm 1.0$ & 35.6 & 0.48 \\
\hline 30 & 5 & $65.5 \pm 3.6$ & $16.4 \pm 0.9$ & 32.4 & 0.49 \\
\hline 40 & 5 & $64.6 \pm 3.9$ & $21.5 \pm 1.3$ & 30.1 & 0.47 \\
\hline 50 & 5 & $60.0 \pm 4.3$ & $25.0 \pm 2.2$ & 23.7 & 0.40 \\
\hline 60 & 5 & $54.5 \pm 5.9$ & $27.2 \pm 2.9$ & 20.0 & 0.37 \\
\hline 70 & 5 & $38.8 \pm 4.3$ & $22.6 \pm 2.5$ & 14.2 & 0.37 \\
\hline
\end{tabular}

${ }^{\mathrm{a}} \mathrm{Mean} \pm \mathrm{SD}$.

Food intake and changes in body weight

Table 3 shows the intakes of food and protein, and changes in body weight in ad libitum fed animals during the experimental period. Food intakes were high in groups given 6 to $20 \%$ casein, ranging from about 70 to $79 \mathrm{~g} / 5$ days, but decreased in other groups with an increase or decrease in the dietary protein level. The food efficiency was highest in the 20 and $30 \%$ casein groups and decreased at higher and lower protein levels. All groups except the 0 and $3 \%$ groups gained body weight depending on the dietary protein level. Changes in body weight of ad libitum fed rats are shown in Fig. 2, together with those of the food-restricted animals. On ad libitum feeding, $20 \%$ casein diet was most effective for growth with the highest efficiencies of food and protein utilization.

\section{Body compositions}

The body compositions of the animals on day 6 and the changes in body protein and fat in 5 days are shown in Table 4 . The body fat contents in all groups of rats fed ad libitum, except the $70 \%$ casein group, ranged from about 12 to $16 \%$. The fat content decreased with the severity of food restriction. The percentage of body protein, expressed on the basis of the lean body mass (LBM), tended to increase with an increase in the dietary protein level at the respective energy intakes.

Starved animals and those given protein-free diet (PFD) ad libitum lost protein and fat during the 5-day feeding period, but other groups retained protein and fat and the 20 and $30 \%$ protein groups showed the greatest deposition. All animals fed restricted amounts equivalent to one-third of the intake of the ad libitum group lost body fat and slightly gained body protein.

Vol. 32, No. 5, 1986 


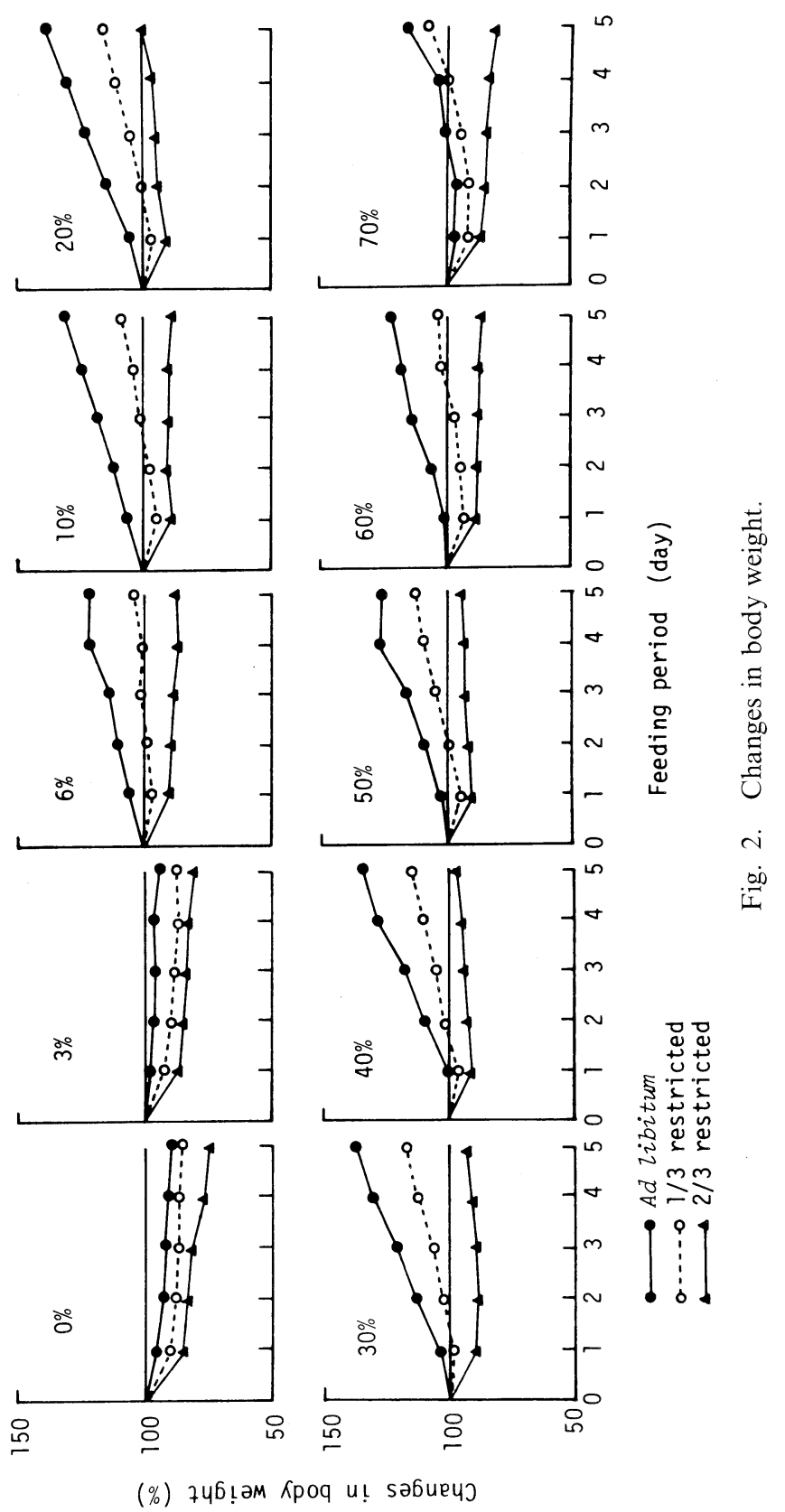




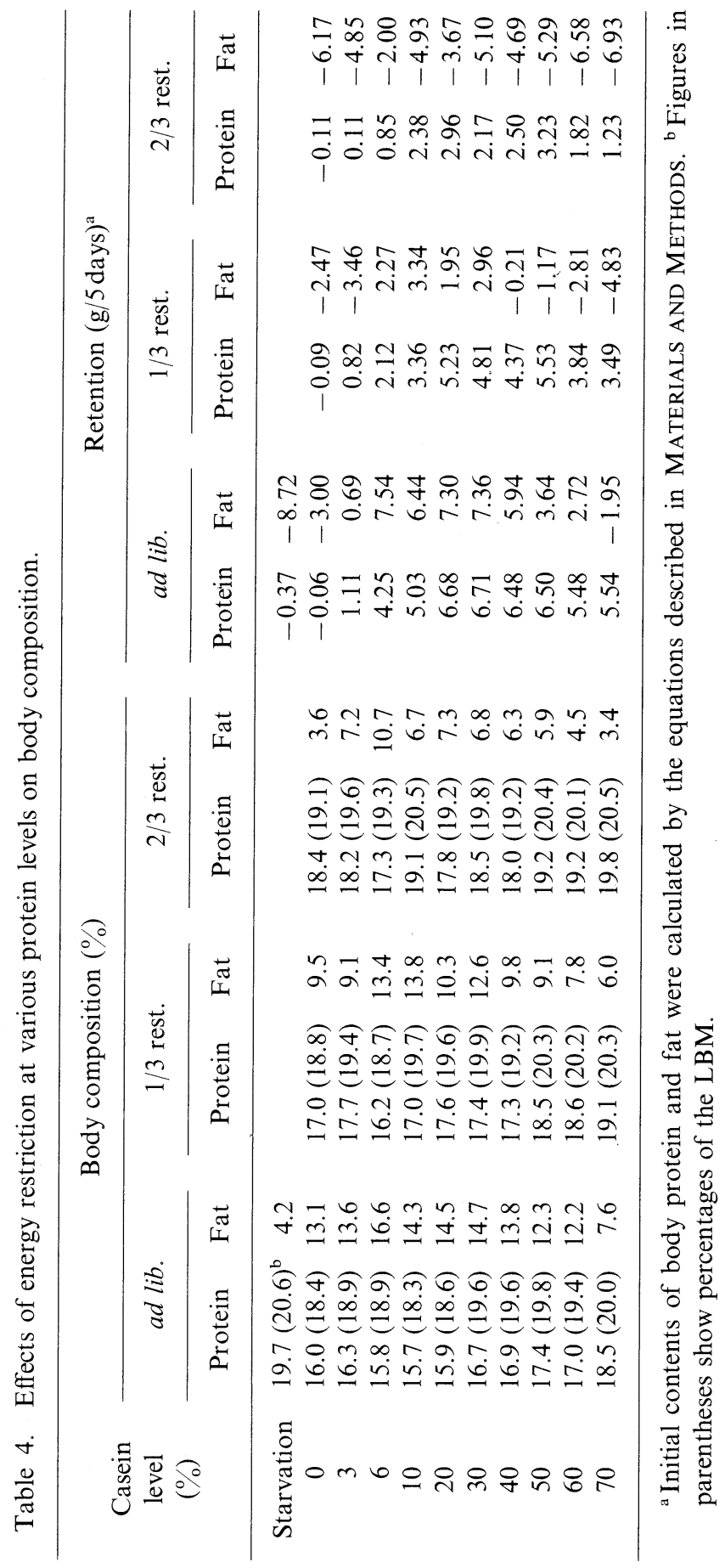


Effect of dietary protein on the 5-day energy balance in animals fed ad libitum

Data from the energy balance study are shown in Table 5, with those on energy retention by the slaughter method. In starving animals, energy expenditure, including fasting heat production and physical activities, decreased markedly in response to starvation. In fed animals, daily energy expenditure ranged from about

Table 5. Effect of dietary protein on energy balance of weanling rats fed ad libitum.

\begin{tabular}{cccccccccc}
\hline $\begin{array}{c}\text { Casein } \\
\text { level } \\
(\%)\end{array}$ & $\begin{array}{c}\text { Intake } \\
\text { energy } \\
\text { (kcal/ } \\
\text { day) }\end{array}$ & $\begin{array}{c}\text { Feces } \\
\text { (kcal/day) in }\end{array}$ & Urine & $\begin{array}{c}\text { Metabo- } \\
\text { lizable } \\
\text { energy } \\
\text { (kcal/day) }\end{array}$ & $\begin{array}{c}\text { Energy } \\
\text { expenditure } \\
\text { (kcal/day) }\end{array}$ & $\begin{array}{c}\text { Balance } \\
\text { (kcal/day) }\end{array}$ & $\begin{array}{c}\text { Energy for } \\
\text { g body } \\
\text { wt. gain } \\
\text { (kcal) }\end{array}$ \\
\hline Starvation & - & 0.24 & 0.44 & -0.68 & 16.57 & -17.25 & $(-16.64)^{\mathrm{a}}$ & - \\
0 & 30.64 & 1.72 & 0.18 & 28.74 & 29.55 & -0.81 & $(-0.63)$ & - \\
3 & 35.67 & 1.82 & 0.20 & 33.65 & 29.70 & 3.95 & $(2.56)$ & - \\
6 & 61.46 & 3.61 & 0.21 & 57.64 & 37.66 & 19.98 & $(18.90)$ & 4.9 \\
10 & 55.74 & 2.88 & 0.32 & 52.54 & 35.88 & 16.66 & $(17.75)$ & 2.9 \\
20 & 60.04 & 3.12 & 1.45 & 55.47 & 35.52 & 19.95 & $(21.25)$ & 2.8 \\
30 & 54.65 & 2.39 & 2.66 & 49.60 & 32.52 & 17.08 & $(21.39)$ & 2.6 \\
40 & 56.09 & 2.33 & 2.91 & 50.85 & 33.88 & 16.97 & $(18.49)$ & 2.8 \\
50 & 53.77 & 2.20 & 3.04 & 48.53 & 34.84 & 13.69 & $(14.23)$ & 2.9 \\
60 & 50.15 & 1.83 & 3.17 & 45.15 & 32.55 & 12.60 & $(11.35)$ & 3.2 \\
70 & 35.55 & 1.19 & 4.39 & 29.97 & 29.28 & 0.69 & $(2.73)$ & 0.3 \\
\hline
\end{tabular}

${ }^{a}$ Figures in parentheses are values determined by the slaughter method.

Table 6. Effect of dietary protein on energy for maintenance and growth.

\begin{tabular}{ccccc}
\hline \multirow{2}{*}{$\begin{array}{c}\text { Casein } \\
\text { level } \\
(\%)\end{array}$} & \multicolumn{3}{c}{ Energy $(\mathrm{kcal} / 100 \mathrm{~g} / \mathrm{day})$} & $\begin{array}{c}\text { Regression } \\
\text { equations }^{\mathrm{d}}\end{array}$ \\
\cline { 2 - 4 } & Metabolizable $^{\mathrm{a}}$ & Maintenance $^{\mathrm{a}, \mathrm{b}}$ & Growth $^{\mathrm{a}, \mathrm{c}}$ & \\
\hline 0 & 32.0 & 35.7 & -3.7 & $Y=0.679 X-24.21$ \\
3 & 36.1 & 31.5 & 4.6 & $Y=0.711 X-22.40$ \\
6 & 55.8 & 30.0 & 25.8 & $Y=0.735 X-22.04$ \\
10 & 49.8 & 29.1 & 20.7 & $Y=0.774 X-22.56$ \\
20 & 49.9 & 29.1 & 20.8 & $Y=0.821 X-23.87$ \\
30 & 46.9 & 28.7 & 18.2 & $Y=0.833 X-23.94$ \\
40 & 48.5 & 29.0 & 19.5 & $Y=0.801 X-23.31$ \\
50 & 47.6 & 29.1 & 18.5 & $Y=0.781 X-22.70$ \\
60 & 44.4 & 30.7 & 13.7 & $Y=0.770 X-23.65$ \\
70 & 31.4 & 34.1 & -2.8 & $Y=0.742 X-25.33$ \\
\hline
\end{tabular}

${ }^{a}$ Refer to Fig. $1 .{ }^{b} X$-intercepts of the respective regression equations. ${ }^{\mathrm{c}}$ Calculated by subtracting MEm from ME. ${ }^{\mathrm{d}}$ Regression equations between ME $(X)$ and energy balance $(Y)$. Correlation coefficients between $X$ and $Y$ were 0.81 or more and significant. 
$30 \mathrm{kcal}$ for the 0,3 and $70 \%$ casein groups to $37.7 \mathrm{kcal}$ for the $6 \%$ casein group.

Energy expenditures ( $Y, \mathrm{kcal} / \mathrm{day}$ ) were proportional to metabolizable energy intakes $(X, \mathrm{kcal} / \mathrm{day})$, and independent of dietary protein levels, as shown by the following equation: $Y=0.33 X+18.22(r=+0.98)$. Energy balance was negative in starved animals and low in the 0 and $70 \%$ casein groups. About 17 to $20 \mathrm{kcal}$ of energy was retained in rats fed 6 to $40 \%$ casein diets.

The energy necessary for $1 \mathrm{~g}$ body weight gain was least in rats receiving $30 \%$ casein diet, amounting to $2.6 \mathrm{kcal} / \mathrm{g}$ (Table 5). The value increased with an increase or decrease in the protein level. The $6 \%$ group retained $19.98 \mathrm{kcal}$ of energy daily, but their weight gain was only $4.1 \mathrm{~g} /$ day, indicating inefficient utilization of energy for growth in protein-deficient animals.

As shown in Table 5, values for energy retention determined by the balance method were similar to those obtained by the slaughter method in the respective groups.

Effect of dietary protein levels on the maintenance energy requirement and utilization efficiency of energy for growth

Table 6 shows the metabolizable energy for maintenance (MEm) and growth (MEg) and the regression equations between energy balance $(Y)$ and metabolizable energy intake $(X)$ in each group in terms of kcal/100 g BW/day. Significant positive correlations were observed in all experimental groups, as shown in the preliminary experiment (Fig. 1). The $X$-intercept of the regression line represents MEm, as stated previously.

The MEm was fairly constant at about $29 \mathrm{kcal} / 100 \mathrm{~g} \mathrm{BW} /$ day in rats given 10 to $50 \%$ casein diets, but increased at higher and lower dietary protein levels. The increase in the $\mathrm{MEm}$ in protein-malnourished rats indicates inefficient energy utilization for body maintenance. Although rats given PFD consumed $32.0 \mathrm{kcal} /$ $100 \mathrm{~g} \mathrm{BW} /$ day of metabolizable energy and lost body weight, their theoretical MEm was calculated to be $35.7 \mathrm{kcal} / 100 \mathrm{~g} \mathrm{BW} /$ day.

From the slopes of the regression lines (Table 6), the net efficiencies for growth were estimated to be $68,71,74,77,82,83,80,78,77$ and $74 \%$ in the $0,3,6,10,20$, $30,40,50,60$ and $70 \%$ casein groups, respectively. Weanling rats fed 20 and $30 \%$ casein diets utilized the dietary energy for growth with highest efficiency. At protein levels higher or lower than 30 or $20 \%$ respectively, the efficiency was lower, indicating that MEg utilization depended on dietary protein. The values of 68 and $74 \%$ for the 0 and $70 \%$ casein groups, respectively, are theoretical values because the rats did not actually grow.

\section{Effects of dietary protein levels and energy intake (degree of food restriction) on organ weights}

Table 7 shows the changes in absolute and relative weights of various organs of rats fed diets containing different protein- and energy-levels for 5 days. Analyses of variance showed that the absolute weights of all organs examined showed sig- 
Table 7. Effects of dietary protein and energy on the absolute and relative weights of rat organs.

\begin{tabular}{|c|c|c|c|c|c|c|c|c|}
\hline \multirow{2}{*}{$\begin{array}{c}\text { Casein } \\
\text { level } \\
(\%)\end{array}$} & \multicolumn{2}{|c|}{ Liver } & \multicolumn{2}{|c|}{ Kidney } & \multicolumn{2}{|c|}{ Heart } & \multicolumn{2}{|c|}{ Spleen } \\
\hline & $\begin{array}{l}\text { Absolute } \\
\text { (g) }\end{array}$ & $\begin{array}{l}\text { Relative } \\
(\mathrm{g} / 100 \mathrm{~g})\end{array}$ & $\begin{array}{l}\text { Absolute } \\
(\mathrm{g})\end{array}$ & $\begin{array}{l}\text { Relative } \\
(\mathrm{g} / 100 \mathrm{~g})\end{array}$ & $\begin{array}{l}\text { Absolute } \\
(\mathrm{g})\end{array}$ & $\begin{array}{l}\text { Relative } \\
(\mathrm{g} / 100 \mathrm{~g})\end{array}$ & $\begin{array}{l}\text { Absolute } \\
\text { (g) }\end{array}$ & $\begin{array}{l}\text { Relative } \\
(\mathrm{g} / 100 \mathrm{~g})\end{array}$ \\
\hline \multicolumn{9}{|l|}{ Ad libitum } \\
\hline 0 & 3.62 & 4.31 & 0.88 & 1.05 & 0.43 & 0.53 & 0.14 & 0.17 \\
\hline 3 & 3.97 & 4.39 & 0.85 & 0.94 & 0.43 & 0.48 & 0.19 & 0.21 \\
\hline 6 & 5.82 & 5.13 & 0.98 & 0.86 & 0.52 & 0.46 & 0.21 & 0.19 \\
\hline 10 & 6.29 & 5.33 & 1.06 & 0.90 & 0.56 & 0.47 & 0.30 & 0.25 \\
\hline 20 & 6.55 & 5.08 & 1.28 & 0.99 & 0.57 & 0.44 & 0.39 & 0.30 \\
\hline 30 & 6.60 & 5.41 & 1.44 & 1.18 & 0.59 & 0.48 & 0.37 & 0.30 \\
\hline 40 & 6.54 & 5.45 & 1.49 & 1.24 & 0.58 & 0.48 & 0.35 & 0.29 \\
\hline 50 & 6.07 & 5.33 & 1.53 & 1.34 & 0.55 & 0.48 & 0.27 & 0.24 \\
\hline 60 & 5.89 & 5.28 & 1.57 & 1.41 & 0.52 & 0.47 & 0.31 & 0.28 \\
\hline 70 & 5.62 & 5.52 & 1.89 & 1.86 & 0.46 & 0.45 & 0.26 & 0.26 \\
\hline \multicolumn{9}{|l|}{$1 / 3$ restricted } \\
\hline 0 & 3.24 & 4.26 & 0.82 & 1.08 & 0.34 & 0.45 & 0.17 & 0.22 \\
\hline 3 & 2.99 & 3.70 & 0.85 & 1.05 & 0.43 & 0.53 & 0.15 & 0.19 \\
\hline 6 & 4.12 & 4.29 & 0.93 & 0.97 & 0.47 & 0.49 & 0.27 & 0.28 \\
\hline 10 & 4.12 & 4.19 & 0.97 & 0.99 & 0.47 & 0.49 & 0.24 & 0.24 \\
\hline 20 & 4.73 & 4.38 & 1.08 & 1.00 & 0.54 & 0.50 & 0.40 & 0.37 \\
\hline 30 & 4.58 & 4.37 & 1.17 & 1.12 & 0.47 & 0.45 & 0.32 & 0.31 \\
\hline 40 & 4.61 & 4.48 & 1.30 & 1.26 & 0.50 & 0.49 & 0.29 & 0.28 \\
\hline 50 & 4.54 & 4.38 & 1.32 & 1.27 & 0.49 & 0.47 & 0.27 & 0.26 \\
\hline 60 & 4.27 & 4.68 & 1.31 & 1.41 & 0.48 & 0.52 & 0.26 & 0.28 \\
\hline 70 & 4.23 & 4.28 & 1.25 & 1.26 & 0.43 & 0.43 & 0.26 & 0.26 \\
\hline \multicolumn{9}{|l|}{$2 / 3$ restricted } \\
\hline 0 & 2.48 & 3.63 & 0.78 & 1.14 & 0.31 & 0.45 & 0.17 & 0.25 \\
\hline 3 & 2.57 & 3.50 & 0.77 & 1.05 & 0.36 & 0.49 & 0.17 & 0.23 \\
\hline 6 & 3.06 & 3.70 & 0.88 & 1.07 & 0.39 & 0.47 & 0.19 & 0.23 \\
\hline 10 & 3.05 & 3.68 & 0.83 & 1.00 & 0.40 & 0.48 & 0.21 & 0.25 \\
\hline 20 & 3.94 & 4.28 & 0.99 & 1.07 & 0.43 & 0.47 & 0.23 & 0.25 \\
\hline 30 & 3.21 & 3.75 & 1.01 & 1.18 & 0.43 & 0.50 & 0.25 & 0.29 \\
\hline 40 & 3.44 & 3.89 & 1.02 & 1.15 & 0.43 & 0.49 & 0.20 & 0.23 \\
\hline 50 & 3.05 & 3.54 & 1.03 & 1.19 & 0.43 & 0.50 & 0.21 & 0.24 \\
\hline 60 & 3.05 & 3.85 & 0.98 & 1.24 & 0.42 & 0.53 & 0.21 & 0.26 \\
\hline 70 & 2.86 & 3.96 & 0.95 & 1.32 & 0.36 & 0.50 & 0.17 & 0.23 \\
\hline \multicolumn{9}{|c|}{$\begin{array}{l}\text { Analysis of variance of } 3 \times 10 \text { factorial experiment } \\
\text { Effect of protein }\end{array}$} \\
\hline & $* * *$ & $*$ & $* *$ & $* * *$ & $* * *$ & NS & $* *$ & * \\
\hline \multicolumn{9}{|c|}{ Effect of energy } \\
\hline & $* * *$ & $* * *$ & $* * *$ & NS & $* * *$ & NS & $* * *$ & NS \\
\hline
\end{tabular}

NS, not significant; ${ }^{*} p<0.05 ; * * p<0.01 ; * * * p<0.001$. 
nificant positive correlations with energy and protein factors in the diet, while the relative weight of the liver showed a significant positive correlation with the energy factor and those of the liver, spleen and kidney showed correlations with the protein factor.

\section{DISCUSSION}

In growing animals metabolizable energy is used for two purposes_-body maintenance and growth. Partition of the ME into MEm and MEg and energetic efficiencies for maintenance and growth may be influenced by many factors, such as the composition of the diet and environmental, chronological and physiological conditions. However, the effects of dietary factors, particularly dietary proteins, have not been examined extensively.

Maintenance energy is considered to be the energy intake at which there is no change in the body energy content and has been evaluated by 1) determination of changes in body energy at various energy intakes around the maintenance level, 2) determination of energy retained after feeding a diet, and 3) regression analysis of energy change on energy intake in animals fed at various energy levels. Of these methods, regression analysis, though rather laborious, is the best because it gives not only values for $\mathrm{MEm}$ but also those for $\mathrm{MEg}$ and net energetic efficiencies for growth (Fig. 1) (2). In addition, if energy changes in the body are estimated by measuring the energy balance without killing the animals, changes in these parameters of energy metabolism can be followed chronologically in the same animals. Thus, regression analysis was used in the present study.

There are reports that the maintenance requirements of various animals, including rats, pigs, steers and sheep, decrease at low levels of nutrition, whereas the other reports did not show any change (3). However, in most previous studies the effects of feed energy, not dietary protein, on MEm have mainly been examined. Therefore, in this study we examined the influence of dietary protein upon the MEm in weanling rats fed diets containing 0 to $70 \%$ casein. As shown in Table 6, MEm was fairly constant over a wide range of dietary protein levels, but was higher in protein deficient rats, indicating that protein deprivation resulted in inefficient energy utilization. Close et al. (4) reported an increased MEm in growing pigs fed a low protein diet. Additional evidence that the MEm increases in protein deficiency is the finding of Inoue $e t$ al. that more energy is needed to maintain body weight in human adults eating a low protein diet (5). The high MEms in the 60 and $70 \%$ casein groups may be partly ascribed to increased DIT due to high protein intakes.

The MEm in rats given PFD was estimated as $35.7 \mathrm{kcal} / 100 \mathrm{~g} \mathrm{BW} /$ day, though they ate $32.0 \mathrm{kcal} / 100 \mathrm{~g} \mathrm{BW} /$ day of $\mathrm{ME}$ and lost weight. It will be interesting to determine whether rats force-fed PFD containing the theoretical amount of MEm $(35.7 \mathrm{kcal} / 100 \mathrm{~g} \mathrm{BW} /$ day) maintain their body weight.

Next, the energy requirements for growth together with the net energetic efficiency should be considered. In growing animals, energy requirements for 
growth include two components-requirement for materials deposited in new tissues (Ed in Fig. 1), and extra energy necessary for synthesis of new tissues ( $\mathrm{MEg}$ - Ed in Fig. 1). In estimating the energy requirements for growth, the latter component has frequently been ignored. For example, the Japanese Committee on Dietary Allowances adopted the figure of $2.64 \mathrm{kcal} / \mathrm{g}$ body weight gain as the energy requirement for growth (6). This value corresponds to Ed, but the actual energy used for growth (MEg) should be considered as the requirement.

In ad libitum-fed weanling rats, the energy used for growth was influenced by the protein level of the diet. As seen in Table 5, it was highest in the $6 \%$ casein group $(25.8 \mathrm{kcal} / 100 \mathrm{~g} \mathrm{BW} /$ day) and decreased gradually with an increase in the dietary protein level. Rats receiving $6 \%$ casein diet used more energy and gained less than the other groups, indicating that the energetic efficiency for growth was low in protein deficiency.

Although net energetic efficiencies for growth have been measured in several species of animals receiving diets containing a given level of protein (7-11), there have been few studies on the effect of dietary protein levels. Close et al. (4) reported that the net energetic efficiencies for energy retention were 74,76 , and $70 \%$ in growing pigs eating diets containing 153,201 , and $258 \mathrm{~g}$ of crude protein $/ \mathrm{kg}$ of dry matter, respectively, showing that the efficiency increased with low protein intakes. However, Campbell and Dunkin (12) found that piglets given an adequate protein $\operatorname{diet}(359 \mathrm{~g}$ crude protein $/ \mathrm{kg}$ of dry matter) exhibited more rapid and efficient growth than those given protein deficient diet ( $134 \mathrm{~g}$ crude protein $/ \mathrm{kg}$ of dry matter) at equivalent levels of energy intake, suggesting decreased efficiency for growth at low levels of protein intake. MacLean and Graham (13) examined the effect of the level of protein intake in isoenergetic diets on energy utilization in six children who received diets containing $4,5.3,6.4$ to 6.7 and $8 \%$ protein energy during randomly assigned dietary periods. The weight gains of these children varied from $2.8 \mathrm{~g} / \mathrm{kg} /$ day for the $4 \%$ group to $6.7 \mathrm{~g} / \mathrm{kg} /$ day for the 6.4 to $6.7 \%$ groups, showing that energy utilization was greatly influenced by dietary protein. The findings of the latter two groups of investigators were confirmed in the present study: the $30 \%$ casein group showed the highest energetic efficiency, $83 \%$, and the efficiency decreased with increase or decrease from this casein level.

More energy was used for growth in the $6 \%$ casein group than in the $30 \%$ casein group, but the net efficiency was more than $10 \%$ less in the former group (Table 6). Thus, the amounts' of energy needed for $1 \mathrm{~g}$ body weight gain in the 6 and $30 \%$ casein groups were calculated to be 4.9 and $2.6 \mathrm{kcal}$, respectively. This finding suggests that rapid and efficient catch-up growth during recovery from proteinenergy-malnutrition cannot be expected on administration of diets rich in inexpensive energy sources. In summary, this study showed that low protein diets resulted in inefficient energy utilization in terms of MEm, MEg and net energetic efficiency for growth. 


\section{REFERENCES}

1) Webster, A. J. F. (1981): The energetic efficiency of metabolism. Proc. Nutr. Sci., 40, 121-128.

2) Millward, D. J., and Garlick, P. J. (1976): The energy cost of growth. Proc. Nutr. Soc., 35, 339-349.

3) Koong, L. J., Ferrell, C. L., and Nienaber, J. A. (1985): Assessment of interrelationships among levels of intake and production, organ size and fasting heat production in growing animals. $J$. Nutr., 115, 1383-1390.

4) Close, W. H., Berschauer, F., and Heavens, R. P. (1983): The influence of protein: energy value of the ration and level of feed intake on the energy and nitrogen metabolism of the growing pig. 1. Energy metabolism. Br. J. Nutr., 49, 255-269.

5) Inoue, G., Fujita, Y., and Niiyama, Y. (1973): Studies on protein requirements of young men fed egg protein and rice protein with excess and maintenance energy intakes. J. Nutr., 103, 1673-1687.

6) Ministry of Health and Welfare (1984): Dietary Allowances of the Japanese: Energy Requirements (in Japanese), Daiichi Publ. Co., Tokyo, pp. 25-49.

7) Canolty, N. L., and Koong, L. J. (1976): Utilization of energy for maintenance and for fat and lean gains by mice selected for rapid postweaning growth rate. J. Nutr., 106, $1202-1208$.

8) Pullar, J. D., and Webster, A. J. F. (1977): The energy cost of fat and protein deposition in the rat. Br. J. Nutr., 37, 355-363.

9) Brooke, O. G., Alvear, J., and Arnold, M. (1979): Energy retention, energy expenditure, and growth in healthy immature infants. Pediatr. Res., 13, 215-220.

10) McNiven, M. A. (1984): The effect of body fatness on energetic efficiency and fasting heat production in adult sheep. Br. J. Nutr., 51, 297-304.

11) Barr, H. G., and McCracken, K. J. (1984): High efficiency of energy utilization in 'cafeteria'- and force-fed rats kept at $29^{\circ}$. Br. J. Nutr., 51, 379-387.

12) Campbell, R. G., and Dunkin, A. C. (1983): The effects of energy intake and dietary protein on nitrogen retention, growth performance, body composition and some aspects of energy metabolism of baby pigs. Br. J. Nutr., 49, 221-230.

13) MacLean, W. C., and Graham, G. G. (1979): The effect of level of protein intake in isoenergetic diets on energy utilization. Am. J. Clin. Nutr., 32, 1381-1387. 